\title{
Academic freedom, integrity and research ethics
}

\author{
Professor Anthony Shannon \\ Fellow, Warrane College, The University of New South Wales, \& \\ Trustee \& Governor, University of Notre Dame Australia \\ E: t.shannon@warrane.unsw.edu.au \\ T: (+61) (0) 402733542 \\ Dr Danielle Eden \\ Academic Lecturer, Australian Institute of Music, \& \\ Adjunct Lecturer in Education, Southern Cross University \\ E: Danielle.Eden@aim.edu.au \\ $\mathrm{T}:(+6)(0) 419177769$
}

\section{Abstract}

The limits, purpose and scope of academic freedom have been the subject of media controversy, partly because academic freedom and academic integrity are close relatives, the occasional missing link being research ethics. While freedom and integrity should protect each another, it is difficult for institutions and those who navigate them to balance competing and conflicting demands. Some of these demands are at the institutional level and others at the individual level. The purpose of this paper is to tease out some of the issues which are often too sensitive to articulate in the public square.

Indexing terms/Keywords: Existential freedom, research ethics, integrity, autonomy, culture, scholarship, free speech, scholarship.

\section{Library of Congress Classification: LC72-72.5}

Type: Expository literature review

Language: English

Date of Submission:

Date of Acceptance: It will be added at the time of publication.

Date of Publication: It will be added at the time of publication.

DOI: It will be added at the time of publication.

ISSN:

Volume: ... Issue: ...

Journal:

Publisher: CIRWORLD

Website: https://cirworld.com

This work is licensed under a Creative Commons Attribution 4.0 International License. 


\section{Introduction}

Academic freedom continues to be a source of controversy. To the extent that it encourages healthy debate and informed discussion in the Academy that is to the good. After, all unbounded freedom is illusory in a democracy; the question is where are the boundaries, a sometimes confronting issue for research students (and their supervisors).

At the institutional level there are issues related to different cultural mores arising from

- multi-campus operations and cross-country collaborations [1],

- globalization with staff and students with different habits and expectations [2].

For the individual academic, affected by these factors, there are also such issues as

- confusion of freedom with 'licence' [3],

- what to teach and how to teach [4],

Are these merely little issues which can be 'sorted out in the wash'? Not according to the long-serving Judge José A Cabranes who has summoned up the current complexities. "We have good news and bad news today. The good news is that we are printing in hard copy the Woodward Report on Freedom of Expression at Yale. The bad news is that we need to reprint the Woodward Report. We are dealing today with interrelated developments at Yale that threaten freedom of expression and the institutions that protect it, including faculty due process rights, sometimes described as academic tenure. Many writers on this subject understandably focus on the fate of students. But it is important to recognize that today's developments are also redefining the rights of faculty-and the role of faculty in the governance of this University. These are developments that, if not addressed, ultimately threaten Yale's place among the great universities of the world" [5].

\section{Meanings}

The University of Notre Dame Australia defines the purpose of their academic freedom policy as "to ensure that Academic Staff Members are able to pursue lines of enquiry and to express views relating to their area of academic expertise" [6]. The freedom for staff to teach, research and communicate within their special competencies and in harmony with the public objectives of the institution which pays their salaries is important for the intellectual health of a higher education institution. This freedom implies not being targeted by the institution on the one hand [7] or subject to cyber bullying - the relatively new other hand [8]. However, to raise issues about academic freedom is pointless without some discussion of freedom in general, because complaints are not infrequently heard about the Dean (who won't let me do this because it conflicts with the objectives of the institution) or the Human Research Ethics Committee which might reject an application because the methodology will not achieve the goals (and so the project would be a waste of time and money)!

Human freedom in general can be distinguished as ontological or existential. The former is the freedom we have by virtue of being human, whereas the latter is the freedom which each person actually has in practice. A person in a prison cell has less physical freedom than someone who is not in a prison cell. The prisoner though may have more mental freedom. This was the existential freedom of Victor Frankl, the great Austrian psychiatrist, who survived the Holocaust and imprisonment in a World War II concentration camp, and who so eloquently expressed his ideas and experiences in his book, Man's Search for Meaning, the title of which encapsulates the theme [9].

Existential freedom is then actual freedom for each person. It can be limited by prejudices and previous lack of experience, or by weaknesses of personality or character, or by limited access to appropriate material or adequate human resources. We are free, as academics, to pursue our intellectual pursuits rigorously or superficially, with enthusiasm which inspires others, or as a matter of routine obligation and boredom. In either case we can inspire our students or dampen their enthusiasm to seek truth, and so we can enrich or restrict their access to their right to academic freedom as students. In the last analysis, it is up to each individual person as Frankl demonstrates.

Interwoven among the metaphysical issues of human dignity, respect, and autonomy, without which human freedom is meaningless in practice, there are the moral boundaries for human ethics committees to consider, 
particularly as some researchers push the boundaries in the pursuit of the idea that if something can be done then it should be done [10]. There is always a measure of uncertainty in research: it would require bravery and ignorance to claim to have written the last word on any topic [11]. In particular, the serendipitous results of curiosity-driven research are important in the long term for the academy: "opportunity to carry out our natural , impulsive, intelligent life, to realize plans, express idea in action or in symbolic formulation, see and hear and interpret all things that we encounter, without fear of confusion, adjust our interests and expressions to each other, is the 'freedom' for which humanity strives [12].

\section{Academic fundamentalism and dominant assumptions}

In August 2017, Amy Wax, the Robert Mundheim Professor at the University of Pennsylvania Law School and Larry Alexander, the Warren Distinguished Professor at the University of San Diego Law School published a joint 'op-ed' in the Philadelphia Inquirer. They noted, with examples, that "there were plenty of things wrong with the US in the 1950s but the basic culture back then helped vastly more than it hurt... all cultures are not equal. Or at least they are not equal in preparing people to be productive in an advanced economy" [13]. The reaction was predictable: 33 (almost half) Wax' colleagues published an open letter condemning her - with assertions only - and without rebutting a single factual claim. Dissent and disagreement are no longer acceptable. One critic of Wax claimed that she was taking academic freedom too far. So what are its limits? Allan wryly noted that "if you are a conservative academic on our campuses you are in a very small minority and if you need promotion you soon learn to keep quiet" [14].

The failure to protect freedom of expression is seriously imperiling the discovery of truth, the core purpose of Australia's universities; student development, which requires debate and challenge; and the future of Australian society, which depends on a tolerance and openness to debate. There are lessons to be learned from previous civilisations [15]. This, In order to protect free speech, Lesh [16] has recommended that Australia's universities:

"(1) abolish policies that limit free speech;

(2) introduce a policy that protects intellectual freedom, as mandated by legislation; and

(3) commit to the University of Chicago's sector-leading statement on free expression" [17].

Newly enrolled students in research degrees often want to attempt too much. When their supervisor says "less is more", they sometimes see this as a curb on their academic freedom, but to let them attempt the impossible in the time available and with the means available is not ethically justifiable.

So too, they can view the requirements of the institution's "Human Research Ethics Committee" as another curb on their methodology and motivation. Yet the answers to what/why/how/when at the outset of a research process are fundamental to its eventual success.

Their third area of complaint can be the mission, vision and objectives of the institution. While much multidisciplinary research can be very productive, the institution has to safeguard its reason for being.

Academic staff too can find any or all of the above as a constraint on their creativity, particularly those who are too readily inclined to bite the hand that feeds them. Their employment contract will have some expectations about scholarship in general, and research in particular, and this has an impact on the corporate budget. Institutions and their academics also need to understand that academic research can benefit the students in two ways: directly in terms of the content, and indirectly through an increase in the inspiration and passion that a re-invigorated mind can bring to teaching even if the content is different in both degree and kind from the scholarly activity.

The Code of Ethics for Researchers" encourages the consideration of seven principles for young researchers to use their academic freedom for the good of society [18]:

- Engage with the public

- Pursue the truth 


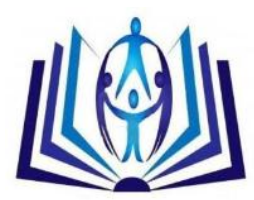

- Minimize harm

- Engage with decision makers

- Support diversity

- Be a mentor

- Be accountable. 
Symons [19] quotes Jodi Halpern at the 2018 World Economic Forum: "People need rigorous education in ethical reasoning ... l'd like to have every doctoral student ... pass a rigorous exam showing how they would deal with certain ethical dilemmas". These are hopeful signs that young researchers will truly value their academic freedom and the responsibilities it brings.

Both staff and students can benefit from annual workshops on the salient features of research ethics which includes discussions and debates on abstracts, literature reviews, clarifying research reading, and organizing research writing so that what is submitted for review by institutional research ethics committees is clear about the research aims, importance and methodology. In particular, it is not ethical to fail to keep reminding researchers about research guidelines, especially good expository writing in literature reviews as the young researcher traverses a four-phase knowledge competency continuum [20]:

$$
\begin{gathered}
\text { unconscious incompetence } \Rightarrow \text { conscious incompetence } \Rightarrow \text { conscious competence } \Rightarrow \text { unconscious } \\
\text { competence! }
\end{gathered}
$$

These are echoes of MacIntyre the University of Notre Dame whose exploration of how normative and evaluative judgements should be understood could well serve as a basis for the continuing professional development of an institution's human research ethics committee [21].

\section{Discussion}

Academic freedom then is not unlimited: staff can be dismissed for gross incompetence, but what about not conforming to 'political correctness' in what they study or the fashion of the day or how they study or the results of their research? The converse of this was when religious institutions tried to coerce their beliefs on scientists or totalitarian societies limited what scientists could study [22]. For instance, scientific research was brought under strict political control in the USSR of the 1930s when some research areas such as genetics and sociology were declared bourgeois pseudoscience [23].

The current irony is that the old left and right socio-political identities and labels have been reversed: it is now the intolerant left who refuse the right of free speech to those whose views they want banished from the public square! [24-27]. To what extent this is failure of leadership in the Academy is a moot point [28]. University leaders are certainly publicly sensitive about free speech, but while they can enunciate the principles, the extent to which they can supervise the practices in a large university is a different matter, particularly when groups deemed to be "conservative" are apparently required to fund their own security [29]. Managerial qualities, if they are dominated by ideology or instrumentalism [30], rather than inspirational scholarly leadership, seem to be valued at a time when governments regard education of their citizens as a cost, and even a financial loss in the budget, rather than as an investment in a country's future.

At least Roman Catholic universities with pontifical status have the scope and limits of academic freedom clearly stated in Sapientia Christiana so that potential academics know the boundaries before they begin employment - even to the extent of clarifying what is a "suitable doctorate" for teaching in a canonical field [31]. Christian universities can contribute to the debate in that, from their viewpoint, freedom requires ideas central to Christian thought and the natural law tradition. Both have been under attack by secular thinkers since the Enlightenment. The first is the idea of freedom of the will, that we really do make choices and are responsible for them. The second is the idea that liberty is bounded by moral norms, that there is a difference between liberty and licence [32].

In an era of growing intolerance, perhaps secular universities could minimize this highly contested issue with more specific institutional charters and codes of conduct! [33]. As most faith-based institutions are private, there can be different approaches to academic freedom between private and public universities even within a single jurisdiction [34]. Moreover, private universities themselves can be distinguished as not-for-profit or entrepreneurial [35], which in turn raises contrasting, if not conflicting, points of view in relation to academic freedom, research and intellectual property [36].

What about the academic freedom of students exposed to brainwashing from lecturers with extreme views on sociological issues? Some students are alert to this, but others have had their sensitivity blunted by thebmedia, or at high school, or countries with a totalitarian regime. Many, of course, will simply conform for assessment purposes, their opinions untouched as they move on. 
Other complicating factors are internationalization of students and globalization of cooperation among academics on an ever increasing scale [37]. In itself, this is to be encouraged but it brings with it the different interpretations of academic freedom in different cultures. It has been difficult among groups of countries which have theoretically embraced cooperation, collaboration and [38]. Internationalization includes multi-campus operations, where even another campus in the same country can raise cultural differences, which are usually exaggerated when a university has another campus in a different country, particularly when the host country is secular and the second country has an officially established religion [39].

\section{Conclusions}

The latest trend in higher education also relates to academic freedom of students as consumers through micro-credentialing, a non-traditional path in which students can gain skill sets in a specific area and receive a credential [40]. Microcredentials can take the form of short course completions, open digital badges, eportfolios, verified certificates, nano-degrees, or other tools that help earners gain a foothold in signalling competencies, skills, and connected networks through a growing system of evidence-rich credentials [41]. The other issues related to academic freedom canvassed above also can complicate this growing phenomenon.

Academic integrity was mentioned in the first sentence of this essay. Professor Jane Fernandez, Vice President (Quality and Strategy), Avondale College of Higher Education, and Dr Kathie Ardzejewska, Manager of the Office of Learning and Teaching, University of Notre Dame Australia, have launched the "Academic Integrity Policy Project" on behalf of the Higher Education Private Providers Quality Network to consider

1. what is the future model for academic Integrity?

2. which areas lack focus in our institutions?

3. what new forms of academic misconduct are not picked up in policy?

4. how effective are the measures we are using to track the effectiveness of the management of academic integrity?

All Australian universities have policies and procedures related to academic integrity that may also be referred to as academic honesty, academic or student misconduct (including plagiarism). These policies define acceptable academic practices and what constitutes misconduct, such as cheating in examinations, plagiarism, collusion or falsification. In the words of Jane Fernandez: "Academic Integrity is the cornerstone of Higher Education. The validity, authenticity and integrity of Standards and Qualifications depend on our management of this."

The Australian regulatory requirements are outlined in Section 5.2 Academic and Research Integrity, Paragraphs 1-4, and Section 6.2 Corporate Governance, Paragraph 4, which states that "The governing body takes steps to develop and maintain an institutional environment in which freedom of intellectual inquiry is upheld and protected, students and staff are treated equitably, the wellbeing of students and staff is fostered, informed decision making by students is supported and students have opportunities to participate in the deliberative and decision making processes of the higher education provider" [42]. These regulations do not touch the pastoral side of the freedom of students. Shrimpton [43] puts it this way in explaining Newman's 'Idea' of the pastoral dimension of university education: "In Newman's age as in our own, well-meaning but counterproductive over-protectiveness at the various stages of education was as common as gross neglect; and then, as now, this was particularly evident at that crucial moment of transition from school to university" ..."the shapeless, relativistic and uninspiring alternatives of contemporary universities ... [which] increasingly function as performance-oriented, heavily bureaucratic, entrepreneurial organizations committed to a narrowly economic conception of human excellence".

In the last analysis academic freedom should be aligned with genuine scholarship within the field or discipline and faithful to the academic virtues enshrined in the objectives of each institution, rather than attempting to follow the latest fashion in research rankings or trying to be "isomorphic with Harvard"! [44], though Harvard is an excellent model for a teaching-intensive university which encourages scholarship which informs teaching.

\section{Conflicts of Interest}


Neither author has a conflict of interest

\section{References}

1. Brown, A. 2006. Academic freedom in Western Europe: Right or privilege? In E. Gerstmann and M.J. Streb (eds). Academic Freedom at the Dawn of a New Century. How Terrorism, Governments and Culture Wars Impact Free Speech. Redwood City, CA: Stanford University Press, pp.115-129.

2. American Association of University Professors. 2015. Statement on Professional Ethics. Baltimore, MD: Johns Hopkins University Press, pp.145-146.

3. Schall, James V. sj. 2018. On 'absolute' non-absolutes: is it ever right to do what is wrong? Mercatornet: Navigating Modern Complexities. 20 February. Mercatornet.com.

4. Kimoga, Joseph, Justine Namaganda, Tom Maigut, Constance Asiimwe, and Caroline Ngabirano. 2017. The perceptions of higher education academic staff on the freedom to decide what to teach. Advances in Social Science Research Journal. 4 (16): Dol:10.14758/assrj.416.3373.

5. Cabrenes, José A. 2017. For Freedom of Expression, For Due Process, and For Yale: The Emerging Threat to Academic Freedom at a Great University. Yale Law and Policy Review: Inter Alia (01/13/2017), http://ylpr.yale.edu/inter alia/freedom-expression-due-process-and-yale-emerging-threat-academicfreedom-great-university.

6. UNDA 2017. Academic Freedom Policy Statement. Fremantle, WA: The University of Notre Dame Australia.

7. American Association of University Professors. 1970. 1940 Statement of Principles on Academic Freedom \& Tenure [with 1970 Interpretive Comments], https://www.aaup.org/ file/1940\%20Statement.pdf.

8. Rowe, John. 2014. Student use of social media: when should the university intervene? Journal of Higher Education Policy \& Management. 36 (3): S. 241-256.

9. Frankl, Victor E. 2006. Man's Search for Meaning. An Introduction to Logotherapy. Fourth Edition. Boston, MA: Beacon Press.

10. Cook, Michael 2017. The Great Human Dignity Heist. Redland Bay, QLD: Connor Court, pp.33-51.

11. Shannon, A.G. 2016. Intuitionistic Fuzzy Logic and Provisional Acceptance of Scientific Theories. In P. Angelov, S. Sotirov (eds). Imprecision and Uncertainty in Information Representation and Processing. Studies in Fuzziness and Soft Computing 332. Berlin: Springer, pp.15-23.

12. Langer, Susanne K. 1979. Philosophy in a new key: a study in the symbolism of reason, rite and art. Third edition. Cambridge, MA: Harvard University Press, p.289.

13. Wax, Amy and Larry Alexander 2017. Paying the price for breakdown of the country's bourgeois culture. Philadelphia Inquirer. August 9.

14. Allan, James. 2017. Coming soon to a campus near you. The Spectator Australia. 9 September, p.vi.

15. Coppens, Philip. 2013. The Lost Civilization Enigma. (Edited by Jodie Brandon.) Pompton Plains, NJ: Career Press Inc.

16. Lesh, Matthew. 2017. Free Speech on Campus Audit 2017. Melbourne, Vic: Institute of Public Affairs.

17. Grieve, Pete. 2016. University to Freshman: Don't Expect Safe Spaces or Trigger Warnings. Chicago Maroon. August 24

18. https://www.weforum.org/communities/young-scientists

19. Symons, Xavier. 2018. “Will a code of ethics make researchers ethical?”. Bioedge. 13 March.

20. Klopper, Rembrandt, Sam Lubbe and Hemduth Rugbeer. 2007. The matrix method of literature review. Alternation. 14 (1): 262-276.

21. Maclntyre, Alasdair. 2016. Ethics in the Conflicts of Modernity: An essay on Desire, Practical Reasoning, and Narrative. Cambridge: Cambridge University Press. 
22. Slater, Eliot. 1978. Review of Sidney Block and Peter Reddaway, Russia's Political Hospitals: Abuse of Psychiatry in the Soviet Union. Journal of Medical Ethics. 4 (2): 100-101.

23. Nye, Mary Jo. 2011. Michael Polanyi and His Generation: Origins of the Social Construction of Science. Chicago, IL: University of Chicago Press.

24. McGucken, William. 1978. On Freedom and Planning in Science: The Society for Freedom in Science 1940-1946. Minerva, 16 (1): 42-72.

25. Andreescu, Liviu. 2009. Foundations of Academic Freedom: Making New Sense of Some Aging Arguments. Studies in Philosophy and Education. 28 (6): 499-515.

26. Tierney, William G., and Michael Lanford. 2014. The Question of Academic Freedom: Universal Right or Relative Term. Frontiers of Education in China. 9 (1): 4-23.

27. Miller, Brian. 2014. Free to manage? A neo-liberal defence of academic freedom in British higher education. Journal of Higher Education Policy \& Management. 36 (2): S. 143-154.

28. Trachtenberg, Stephen Joel, Gerald B. Kauvar, E. Bogue, and E. Grady. 2013. Presidencies Derailed: Why University Leaders Fail and How to Prevent It. Baltimore, MD: Johns Hopkins Press.

29. Spence, Michael. 2017. We limit free expression? Nothing could be further from the truth. The Australian. August 8, p.12.

30. Franklin, James. 1999. The Sydney Philosophy Disturbances. Quadrant. 43 (4): 16-21.

31. Pope John Paul II. 1979. Sapientia Christiana. Vatican City: Libreria Editrice Vaticana.

32. Hill, John Lawrence. 2016. After the Natural Law: How the Classical Worldview Supports Our Modern Moral and Political Views. San Francisco, CA: Ignatius Press.

33. Berdahl, Robert. 1990. Academic freedom, autonomy and accountability in British universities. Studies in Higher Education. 15 (2): 169-180.

34. Gideon, Andrea. 2015. Blurring Boundaries between the Public and the Private in National Research Policies and Possible Consequences from EU Primary Law. Journal of Contemporary European Research. 11(1): 50-68.

35. Schulte P. 2004. The entrepreneurial university: A strategy for institutional development. Higher Education in Europe. 29 (2): 187-191.

36. Leisyte, Ludvika, and Jay R. Dee. 2012. Understanding Academic Work in a Changing Institutional Environment. In John C. Smart, Michael B. Paulsen, Higher Education: Handbook of Theory and Research, Dordrecht: Springer, pp.123-206.

37. Lindberg-Sand, Åsa. 2012. The Embedding of the European Higher Education Reform at the Institutional Level: Development of Outcome-Based and Flexible Curricula? In Adrian Curaj, Peter Scott, Lazăr Vlasceanu, Lesley Wilson (eds). European Higher Education at the Crossroads: Between the Bologna Process and National Reforms Part 1. Dordrecht: Springer, pp.191-208.

38. Edwards, R., G. Crosling, and N-C. Lim. 2014. Organizational Structures for International Universities: Implications for Campus Autonomy, Academic Freedom, Collegiality, and Conflict. Journal of Studies in International Education. 18 (2): 180-194.

39. Streitwieser, Bernard (ed). 2014. Internationalisation of higher education and global mobility. Didcot, Oxford: Symposium Books.

40. Norton, Andrew. 2016. Mapping Australian higher education 2016. Melbourne: Grattan Institute, Ch.2.

41. Reid, Alan J., Denise Paster, and Samuel Abramovich. 2015. Digital Badges in Undergraduate Composition Courses: Effects on Intrinsic Motivation. Journal of Computer Education 2 (4): 392.

42. Birmingham, Simon. 2015. Higher Education Standards Framework. Canberra: Australian Government Department of Education and Training.

43. Shrimpton, Paul. 2014. The 'Making of Men': The Idea and reality of Newman's university in Oxford and Dublin. Leominster, UK: Gracewing, pp. xxxiv-xxxvii.

44. Boyer, Ernest L. 2016. Scholarship Reconsidered: Priorities of the Professoriate. [Updated and Expanded by Drew Moser, Todd C Ream, John M Braxton and Associates.] The Carnegie Foundation for the Advancement of Teaching. San Francisco, CA: Jossey Bass. 